\section{Space telescope lands new career in bomb detection}

NASA's Compton Gamma Ray Observatory plunged into the Pacific Ocean, in a planned de-orbit, in 2000. But its spare parts are now being used to help detect dirty bombs.

James Ryan, an astrophysicist at the University of New Hampshire in Durham, has recycled parts from one of the telescope's old instruments. He aims to detect $\gamma$-rays emitted by radioactive substances, such as plutonium, uranium and caesium. These elements could be used in bombs that combine conventional explosives with radioactive material.

"If we can detect aluminium-26 on the other side of the Galaxy, we can detect this stuff on the other side of the street," says Ryan, who presented results from a prototype detector on 12 May in Boston, at a conference sponsored by the Institute of Electrical and Electronics Engineers and the US Department of Homeland Security.

\section{Farm bill reduces support for corn ethanol}

US lawmakers have agreed on wide-ranging agricultural legislation that would reduce the federal subsidy on ethanol produced from maize (corn) by $12 \%$. It marks the first move to scale back government support for a biofuel that has been linked to rising food prices and deforestation abroad.

The farm bill, worth nearly $\$ 300$ billion, would direct federal agricultural policy for the next five years, doling out money for agricultural subsidies, nutrition programmes, conservation projects and international food aid. It would reduce the maize ethanol subsidy from 51 to 45 cents per gallon; critics have called for its complete elimination. The bill also creates new incentives for the development of advanced biofuels that would not compete with food crops.

The bill is expected to clear Congress this week. But the White House says it will veto the bill because it fails to reduce agricultural subsidies at a time when rising crop prices are lining farmers' pockets.

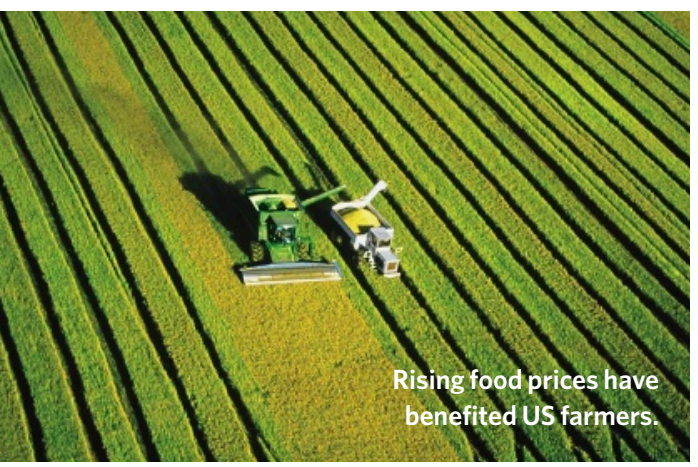

\title{
Forest clearance boosted power of Cyclone Nargis
}

As the death toll from Cyclone Nargis climbs to an estimated 100,000 or even higher in Myanmar researchers are working to identify the factors that made it so deadly.

The category-4 Nargis, which struck Myanmar on 2 May, has far surpassed the death toll of Cyclone Sidr, which killed at least 3,500 people in Bangladesh last

November, and is approaching that of the 1991 Bangladesh cyclone, which killed some 138,000.

Mangroves and coastal forests

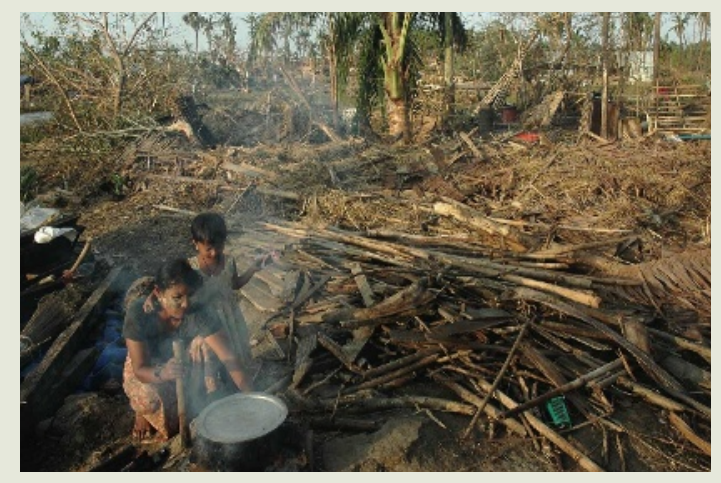

in Myanmar's Irrawaddy Delta have been extensively cleared in the past decade, mainly to make way for shrimp farms and rice paddies. The loss of that natural protective barrier intensified the destruction, conservation experts say. Areas where mangroves had been conserved saw less destruction than other regions in the 2004 Indian Ocean tsunami.

\section{Cosmologist quits Britain over poor physics funding}

A leading cosmologist is leaving the United Kingdom for Canada, in part, he says, because of the government's attitude towards funding physics research.

Neil Turok, a cosmologist at the University of Cambridge, says that recent funding cuts for fundamental physics in Britain "played a big role" in his decision to take up the post of executive director at the independent, nonprofit Perimeter Institute for Theoretical Physics in Waterloo, Ontario. Turok says the cuts, and a desire for more applied research, are "the latest in a long history of the [government's] misunderstanding of the role of basic science".

Turok will bring valuable research and leadership experience to the institute, says Perimeter's founder, Mike Lazaridis.

\section{Hefty funds lay foundations for stem-cell facilities}

The California Institute for Regenerative Medicine (CIRM), the state's stem-cell agency, has awarded \$271 million to 12 institutions to seed a building boom of research facilities across the state.

The awards were made at the CIRM's 7 May meeting. The largest, \$44 million, went to Stanford University in Palo Alto; the smallest, \$3 million, went to the University of California, Santa Barbara. Every

University of California campus except Riverside received an award, as did the Buck Institute for Age Research in Novato; the University of Southern California in Los Angeles; and a consortium of four San Diego institutions called the San Diego Consortium for Regenerative Medicine (see Nature 453, 18-21; 2008).

California institutions hope the new facilities, scheduled to be completed in two years, will help them recruit more scientific talent. The new buildings will be a boon for scientists working on human embryonic stem cells, but will also aid those studying other aspects of regenerative medicine, such as adult stem cells and immunology.

\section{Former NASA science director returns to post}

Long-time NASA employee Ed Weiler has been named permanent director of the agency's US\$5-billion science division, returning to a position he held between 1998 and 2004.

Weiler, an astrophysicist, replaces Alan Stern, a planetary scientist who resigned in March after a dust-up with NASA chief Michael Griffin over the Mars exploration budget. Weiler himself is no stranger to such arguments; in 2004, he and Sean O'Keefe, NASA's then head, had differing views on whether a robotic servicing mission to the Hubble Space Telescope was a good idea. Later that year, Weiler took over directorship of NASA's Goddard Space Flight Center in Greenbelt, Maryland.

In general, Stern was praised by space scientists for his desire to boost launch rates and research funding. He also enforced a strict accountability for mission cost overruns (see Nature 448, 978; 2007), which ruffled some feathers, especially within the Mars community.

NATURE.COM WINS A WEBBY

Nature.com has been named as the Best Science Website of 2008 in the 12th Annual Webby Awards (www.webbyawards.com). Hailed as the 'Oscars of the Internet' by The New York Times, the Webby Award winners are chosen by the International Academy of Digital Arts and Sciences (IADAS), a global organization of industry experts and technology innovators. 